\title{
¿DESPEJAR LA INTELIGENCIA Y FORTALECER EL ESPÍRITU! \\ UNAS ESCUELAS PARA LAS PALMAS DE GRAN CANARIA, UN PROYECTO FRUSTRADO DE LAUREANO ARROYO
}

\author{
Ana María Quesada Acosta* \\ Universidad de La Laguna
}

\section{RESUMEN}

Este artículo aborda el proyecto de unas escuelas que Laureano Arroyo, en calidad de arquitecto municipal, traza en 1891. La carencia de edificios para la instrucción primaria en Las Palmas de Gran Canaria hizo que el Ayuntamiento se plantease, en distintas ocasiones del Ochocientos, solicitar una subvención que el Ministerio de Fomento concedía a los municipios, a fin de que los interesados pudiesen contar con esa tipología arquitectónica. Con el ánimo de contextualizar esta fracasada empresa hemos dividido la investigación en tres partes. En la primera exponemos una serie de datos que revelan el previo proceder de la Corporación en relación con sus maestros y con las dependencias que destinaban a tal fin, lo que nos ayuda a comprender la razón de su dictamen. En la segunda referimos los datos del proyecto, mientras que en la tercera ponemos en relación el mismo con la trayectoria del facultativo.

Palabras clave: Laureano Arroyo, Las Palmas de Gran Canaria, Ayuntamiento, escuela, enseñanza, proyecto.

CLEAR THE INTELLIGENCE AND STRENGTHEN THE SPIRIT! SOME SCHOOLS FOR

LAS PALMAS DE GRAN CANARIA, A FRUSTRATED PROJECT OF LAUREANO ARROYO

\section{Abstract}

This article deals with the project for some schools wich Laureano Arroyo, as municipal architect, drew up in 1891. The lack of buildings for primary education in Las Palmas de Gran Canaria led the City Council, on various occasions in the 19th century, to consider applying for a grant wich the Ministry of Development awarded to municipalities, to enables those interested to have this type of architecture. In order to put this failed enterprise into context, we have divided the research into three parts. In the first part, we present a series of data that reveal the previous actions of the City Council in relation to its school teachers and the buildings that were used for this purpose, which helps us to understand the reason for its report. In the second part we refer to the data about the project, while the third part is related to the trajectory of the arquitect in question.

Keywords: Laureano Arroyo, Las Palmas de Gran Canaria, City Council, school, education, project. 


\section{BREVES REFERENCIAS SOBRE LA INSTRUCCIÓN PRIMARIA MUNICIPAL EN LA CIUDAD}

A principios del Ochocientos, Las Palmas de Gran Canaria contaba solamente con dos escuelas públicas, una en Vegueta y otra en Triana ${ }^{1}$, regentadas, respectivamente, por Pedro Afonso y Francisco Zumbado. Hasta 1823, estos docentes carecerán de apoyo económico municipal; en esa fecha, tras una Real Orden que los nombraba titulares, comienzan a percibir, anualmente, 500 pesos como retribución. Sin embargo, poco disfrutarán de tales rentas, pues ese mismo año, al abolirse la Constitución, les serán denegadas².

Según se desprende de un informe realizado por el Consistorio en 1834, a petición del gobernador civil, la situación no había mejorado, si bien ahora se indica que los dos únicos centros para la instrucción primaria estaban localizados en Vegueta y destinados exclusivamente a varones, "pues aunque no faltan personas que se dediquen a la enseñanza de algunos niños, estas con propiedad no pueden llamarse escuelas» ${ }^{3}$. El pobre resultado da pie a que la comisión investigadora sometiese a debate de los munícipes una iniciativa que abogaba por aumentar a seis los puntos docentes, cuatro para varones y dos para niñas. El pleno, aduciendo escasez de fondos con que dotarlas, rebaja la opción a cuatro, en número de dos para cada sexo. Esta equiparación, en cuanto a locales se refiere, no se correspondió, curiosamente, con los salarios que acuerda satisfacer a los maestros, pues mientras que a los de los chicos se les dota con una pensión de 400 pesos, a los de las niñas se les asigna tan solo la cantidad de $150^{4}$.

Sin embargo, en 1836, esta decisión no se aplicaba estrictamente en el sentido acordado, ya que el Ayuntamiento se limitaba a efectuar la dotación de una escuela, debiendo el interesado habilitar a tal fin algunas de las dependencias de su

* Profesora titular de Historia del Arte, Facultad de Humanidades, Departamento de Historia del Arte y Filosofía, Universidad de La Laguna. Edificio Departamental de Geografía e Historia, Campus de Guajara, s/n, San Cristóbal de La Laguna, 38071. Correo electrónico: aquesada@ ull.edu.es. Orcid 0000-0002-5588-8292.

Navarro, Domingo J. (1991): Recuerdos de un noventón, Las Palmas de G. C., Ediciones El Museo Canario, p. 71; sobre el origen y características de la instrucción pública primaria, consultar Negrín Fajardo, Olegario (1982): La enseñanza en Canarias, Colección «La Guagua», n. ${ }^{\circ} 42$, Las Palmas de Gran Canaria, Mancomunidad Interinsular de Cabildos de Las Palmas.

2 Álamo, Néstor (1857): «El Gabinete Literario. Crónica de un siglo 1844-1944». Folletón publicado en Diario de Las Palmas, Las Palmas de Gran Canaria, f. 17v.

${ }_{3}$ Archivo Municipal de Las Palmas de Gran Canaria (en adelante AMLPGC). Libro de Actas del año 1834, sesión del 29 de octubre, s. f.

${ }^{4}$ Archivo de la Real Sociedad Económica de Amigos del País (en adelante ARSEADP); 2. Informes. 2.3. Enseńanza y Medicina. Expediente sobre el establecimiento en esta ciudad de una escuela del sistema denominado Jardines de Infancia. Padilla y Padilla, Pablo (1874): Memoria leida el 29 de abril de 1874. A los alumnos de las escuelas de Instrucción pública de Las Palmas de Gran Canaria. Imp. La Verdad, Gran Canaria, pp. 6-9. Memoria Digital de Canarias, Universidad de Las Palmas de Gran Canaria. Fecha digital: 2005-2007; Suárez FalCón, José (1920): Historia de los establecimientos de enseñanza en Las Palmas, Las Palmas de Gran Canaria, p. 19. 
vivienda. Así lo deducimos de un escrito que le eleva el maestro, el ya citado Pedro Afonso, concretamente en el mes de junio, recordándole la promesa que le había expresado siete meses antes -cuando precisamente había abierto una escuela pública en Vegueta-, acerca de proporcionarle algunas de las piezas del convento de San Agustín ${ }^{5}$. En distintas ocasiones, al igual que lo hará su colega Francisco Doreste, quien desde 1837 regentara la ubicada en Triana ${ }^{6}$, Afonso se enfrentará a la municipalidad a fin de que no hiciese dejación de sus obligaciones, tanto en lo que se refiere a la asignación de salas como a los estipendios laborales. Ilustrativo al respecto es parte del escrito que en 1842 dirigen conjuntamente a la Alcaldía:

... cansados ya de escribir a esta I. Corporación la triste y lamentable situación en que se hallan por la falta absoluta del pagamento de sus sueldos vuelven por última vez a recurrir a esta municipalidad, manifestando, que si a la mayor brevedad no se sirve proporcionar fondos con que sacarlas de la miseria y abandono en que hace tanto tiempo se hallan, se verán precisamente en la dura necesidad de cerrar sus escuelas, despidiendo el crecido número de jóvenes que bajo su dirección reciben graciosamente la primera enseñanza, acontecimiento que haría muy poco favor a estos ilustrados habitantes, y redundaría en descrédito y menoscabo de las actuales instituciones?

Dos años después, la situación había mejorado en algo, recuperando Vegueta y Triana la posibilidad de contar, respectivamente, con una escuela femenina ${ }^{8}$. Asimismo, de su precario presupuesto pudo disponer el Ayuntamiento, a instancias de la Comisión de Instrucción Primaria, 600 reales de vellón para facilitar los premios a los alumnos más destacados en los exámenes generales?. Con todo, en ocasiones, se vio obligado a recurrir a la suscripción pública en aras de facilitar los útiles precisos para las escuelas ${ }^{10}$. De nuevo, en 1845 , la situación se torna crítica, al derivar en un estado de abandono que será duramente criticado por la autoridad gubernativa, la cual, en abril, llega incluso a amenazar a los munícipes con una multa de 1000 reales de vellón, si no remediaban en un mes «la miseria con que el Ayuntamiento tiene sus escuelas, lo poco decente del local, la escasez de utensilios para su uso y la poca exactitud en el pago de los maestros»" ${ }^{11}$. Del escrito se deduce que para entonces, la entidad había proporcionado algunas dependencias, hipótesis que nos puede corroborar la petición que la Comisión de Instrucción Primaria haría al

${ }^{5}$ Archivo Municipal de Las Palmas de Gran Canaria (en adelante AMLPGC). Libro de Actas del año 1836, sesión del 26 de junio, s. f.

${ }^{6}$ Suárez Falcón, José (1920): op. cit., p. 20.

7 AMLPGC. Libro de Actas del año 1842, sesión del 11 de julio, s. f.

${ }^{8}$ En febrero de 1844 se nombraban maestras para niñas de Triana y Vegueta, respectivamente, a dońa Josefa Matos y dońa Dolores Jiménez. Suárez Falcón, José (1920): op. cit., p. 21; AMLPGC. Libro de Actas del año 1844, sesión del 26 de febrero, s. f.

9 AMLPGC. Libro de Actas del año 1844, sesión del 3 de diciembre, s. f.

10 AMLPGC. Libro de Actas del año 1845, sesión del 15 de abril, s. f.

11 AMLPGC. Libro de Actas del año 1845, sesión del 3 de octubre, s. f. 
año siguiente, rogándole la inversión de algún dinero en las reparaciones más apremiantes de los locales ${ }^{12}$.

Lo cierto es que a partir de entonces, el Ayuntamiento comienza a dedicar más atención a la primera enseñanza, en respuesta suponemos a los distintos dictámenes gubernamentales que sobre esta materia se van estableciendo a favor de la instrucción pública gratuita, responsabilidad que recaerá definitivamente en los alcaldes, tras aprobarse la Ley Moyano en $1857^{13}$. Es por ello por lo que ya en ańos previos a ésta, y en los sucesivos, el número de escuelas va aumentando paulatinamente a lo largo de la ciudad, y barrios como Los Arenales, San José, así como los pagos de Tafira y Marzagán, disfrutarán también, con el paso del tiempo, de los beneficios del aprendizaje.

Es más, entre las acciones que reflejan la actitud municipal en pro de la enseñanza elemental, nos consta la solicitud que ya en 1852 expone el Consistorio a Beneficencia, a fin de que le arrendase una casa que anteriormente había cedido para cuartel del Regimiento, con el propósito de instalar una nueva escuela, haciendo saber que en el supuesto de que se le concediera, procedería a derribar las paredes divisorias de las tres habitaciones con que contaba, a efectos de lograr un salón cómodo y capacitado ${ }^{14}$. La petición es atendida con la expresa condición de que el Ayuntamiento abonara la contribución del alumbrado público, además del alquiler estipulado, imponiéndole también que una vez desalojado, en un futuro, debería levantar de nuevo las paredes, dejándola en idéntica disposición que antes ${ }^{15}$.

Esa misma actitud implicatoria la demuestra el Consistorio, un año después, al sacar a subasta un molino, denominado «Portichuelo», sito en la jurisdicción de Telde, con el objeto de aplicar el producto a cubrir los gastos de la enseñanza primaria ${ }^{16}$. Elocuente al respecto es también el hecho de que en 1861 el Ayuntamiento entregaba 200 pesos al maestro Manuel Castro para ayudarle a ejecutar remodelaciones en su casa, con el fin de que las niñas que asistían recibieran cómodamente

12 AMLPGC. Libro de Actas del año 1846, sesión del 16 de abril, s. f.

${ }_{13}$ El primer Decreto que determina la enseńanza gratuita se firma el 29 de junio de 1821. Le seguirán el Reglamento General de Primera Enseñanza de 1822, el Plan de Escuelas de Primeras Letras aprobado en 1825, el Plan de Instrucción Primaria de 21 de julio de 1838, el Reglamento de 26 de noviembre de 1838, la Real Orden de 12 de julio de 1849 . Sobre estas normativas y la enseńanza en Canarias debe consultarse Puerta Canseco, Juan de la: «La primera enseñanza en Canarias", Revista de Canarias, n. ${ }^{\circ}$ 12, 23-5-1879 y Oramas Luis, José Antonio: La escuela Normal de La Laguna en el siglo XIX, Cabildo de Tenerife, 1992.

${ }_{14}$ AMLPGC. Libro de Actas del año 1852, sesión del 7 de diciembre, s. f.

15 AMLPGC. Libro de Actas del año 1852, sesión del 15 de diciembre, s. f.

16 El hilo de dicha subasta se fijó en 300 reales de vellón y las condiciones fueron las siguientes: $1 .^{a}$, el remate sería por un año y a todo riesgo; $2 .^{a}$, correrían por cuenta del rematador los costes que ocasionaran los enseres del molino; $3 .^{a}$, satisfaría aquél trimestralmente al depositario del Ayuntamiento la cuarta parte del importe, y $4 .^{\text {a }}$, el rematador debía presentar un fiador. AMLPGC. Libro de Actas del año 1853, sesión del 20 de octubre, s. f. 
la docencia ${ }^{17}$. Y ese mismo año, se comprometía a reparar el techo del salón de la escuela localizada en la plaza de San Francisco ${ }^{18}$.

A decir de Pablo Padilla y Padilla, a la sazón presidente de la Junta Local de Primera Enseńanza de Las Palmas de Gran Canaria, en 1874, en una memoria que analiza la situación docente, se había alcanzado la cifra de diecinueve escuelas, un elevado número que estaba pronto a incrementarse, con la apertura de nuevos centros destinados a ambos sexos en los barrios de San Cristóbal, Puerto de La Luz, San Lázaro, San Nicolás y San Roque, lo que situaría a la ciudad en un «lugar distinguidísimo entre los pueblos más ilustrados del globo, por lo que la primera enseñanza basada en sólidos principios y con la amplitud que en nuestras escuelas se enseña, es fundamento cierto de la verdadera civilización» ${ }^{19}$.

Los datos expuestos en páginas previas revelan cierto interés municipal por atender debidamente las necesidades de la enseñanza, pero también es verdad que resultan bastante elocuentes de la parquedad, en general, de las arcas municipales, un erario que debía atender a múltiples reformas urbanas, arquitectónicas, sociales y económicas, que van surgiendo a lo largo de esa convulsa centuria. Por ello, las referencias a las deudas contraídas con los maestros, a la necesidad de acudir a donativos populares o a arrendar algunas propiedades para dotar a los centros del instrumental necesario justifican el hecho de que, en ningún momento, las distintas corporaciones municipales que se sucedieron a lo largo de las seis primeras décadas tantearan la posibilidad de levantar un edificio para dedicarlo exclusivamente a la instrucción de los menores.

Alguna que otra oportunidad de colaboración económica gubernamental tuvo el Ayuntamiento, pero todo parece indicar que se dejó escapar, no imitando, por ejemplo, la actitud de los munícipes de Valleseco, quienes acogiéndose a una Real Orden de 24 de julio de $1856^{20}$, elevaban cuatro años después un expediente para solicitar una subvención con la que erigir una escuela de niñas ${ }^{21}$. El 25 de febrero de 1863, la Gaceta de Madrid se hacía eco de la concesión de la asistencia económica, 400 escudos, financiados por el Ministerio de Fomento. En la memoria descriptiva del proyecto se indica que el inmueble contaría con una clase, una habitación para la maestra, un patio común y un excusado ${ }^{22}$.

${ }_{17}$ AMLPGC. Libro de Actas del año 1853, sesión del 28 de junio, s. f.

18 AMLPGC. Libro de Actas del año 1861, sesión del 4 de febrero, s. f.

19 ARSEADP. LPGC. 2. Informes. 2.3. Enseñanza y Medicina. Expediente sobre el establecimiento en esta ciudad de una escuela del sistema denominado Jardines de Infancia. Padilla Y Padilla, P. (1874): op. cit., pp. 6-7.

${ }^{20}$ Esta Real Orden ofrecía una ayuda económica a los ayuntamientos, para que establecieran escuelas municipales, que oscilaba entre 20000 y 30000 pesetas. Galante Gómez, Francisco (1989): El ideal clásico. Arquitectura Canaria, Las Palmas de Gran Canaria, EDIRCA, p. 156.

${ }^{21}$ Archivo Municipal de Valleseco (en adelante AMV). Libro de Actas del año 1860, sesión del 26 de julio, s.f.

${ }_{22}$ AMV. Archivador Documentación Histórica (1858-1864). Memoria descriptiva de una escuela para niñas (25-10-1865), s.f. 


\section{PROYECTO DE UN EDIFICIO PARA ESCUELAS}

\subsection{Orígenes de LA TENTATIVA}

Tenemos que esperar hasta septiembre de 1875 para que el Ayuntamiento de Las Palmas debata, por primera vez en un pleno, la necesidad de contar con un edificio donde impartir la enseñanza elemental. Fue el entonces alcalde, Luis Navarro Pérez, quien expone la idea, mediante un discurso alusivo a los desvelos del Gobierno por fomentar la instrucción pública y la importancia que ésta tenía en toda sociedad que se preciara de culta. Como ejemplo a sus aseveraciones, cita el caso de Alemania, nación que presentaba el mayor porcentaje relativo de escuelas, razón por la que «marcha a la cabeza de la civilización universal y es luminoso centro de las ciencias filosóficas y exactas y emporio de la industria y de las artes» ${ }^{23}$.

Una visión muy similar y tan estimulante como la expresada por Pablo Padilla tan sólo un año antes en su citada memoria. Palabras elocuentes que quizá sirvieron de aliento al primer edil, si bien es verdad que el Ayuntamiento necesitaba más que buenos augurios para concretar su idea, de modo que ésta no responde tanto a este hecho como a la coyuntura que le brinda la legislación entonces vigente, un Real Decreto dispuesto por el Ministerio de Fomento el 22 de julio del ańo anterior. Propiciaba éste, al igual que el de 1856, la concesión de subvenciones a los municipios para construir escuelas, una propuesta encaminada a ayudar, particularmente, a todos aquéllos que potenciaban la docencia, pero que carecían de medios para edificar, por su cuenta, inmuebles de esta tipología. Navarro considera que Las Palmas de Gran Canaria podía figurar perfectamente en ese grupo de localidades y, en consecuencia, propone la posibilidad de acogerse a la normativa. Pese a que el órgano concejil apoya por unanimidad la iniciativa, lo cierto es que nada se tramita al respecto $^{24}$. Tal vez, la falta de resolución se debiera al escaso tiempo que le quedaba en el poder a este grupo político -aproximadamente un mes-, ya que Juan José María León y Joven asumiría la presidencia de una nueva Corporación el 15 de octubre de ese mismo año. Durante su gestión nada se debate al respecto.

Se dejaba pasar así una nueva oportunidad que sí supieron aprovechar otros municipios canarios, entre ellos, Arrecife, Lanzarote. En 1878 encomendaba un proyecto al arquitecto de la Diputación Provincial, Manuel de Oráa, quien diseñó un edificio de usos varios: dependencias municipales, juzgados, tres aulas para docen-

${ }^{23}$ AMLPGC. Libro de Actas del año 1875, sesión del 2 de septiembre, s. f.

${ }^{24}$ Ibidem. La Real Orden aludida, publicada en Gaceta de Madrid, 26-7-1887, expone en su artículo segundo: "Cuando el expediente resulte que en ningún año del sumario se ha rebajado el presupuesto de la primera enseñanza, tendrá el pueblo reclamante derecho al 50 por 100 del importe de las obras que en sus Escuelas proyecte, pero si el presupuesto ofreciese un aumento confirmado en dicho capítulo del 2 por 100 anual, la subvención podrá llegar al 75 por 100 según aprecien los sacrificios hechos por el pueblo, la Dirección del ramo y el Consejo de Instrucción Pública». 
cia con capacidad para 70 u 80 alumnos y una habitación destinada a los maestros. A sus trazas se debió también el pertinente mobiliario ${ }^{25}$.

También a Manuel de Oráa le recaba la isla de La Palma, en dos ocasiones, distintos proyectos de escuelas. A la primera, protagonizada por el Ayuntamiento de Los Llanos de Aridane, responde negativamente, aduciendo que en esos momentos le resultaba imposible. Respuesta similar recibe el Consistorio de Breña Alta, alegando que sus múltiples trabajos le impedían abordar el proyecto, pero sugiriendo ahora que se le abonaran los honorarios a cualquier otro arquitecto particular. Finalmente, de los croquis solicitados se hizo cargo Felipe de Paz y Pérez, trazas que precisamente desestimará el arquitecto provincial, en su pertinente supervisión, por carecer el comisionado de formación en arquitectura ${ }^{26}$.

En lo que respecta a Las Palmas de Gran Canaria, no será hasta finales de 1886, bajo la alcaldía de Fernando Delgado Morales, cuando se exponga de nuevo la iniciativa de contar con un edificio para escuelas. En esta ocasión, la propuesta llega a manos del concejal Tomás de Zárate, quien la presenta también ante la Real Sociedad Económica de Amigos del País, siempre atenta a las necesidades culturales de la población. Por segunda vez, la tentativa es vista con buenos ojos por la municipalidad y apoyada ahora, además, por los miembros de dicha entidad cultural. Ambos organismos configuran sendas comisiones representativas, pero el paso del tiempo demuestra que, también en este momento, la intención no pasó de ser un buen propósito. Si atendemos a un artículo publicado en el periódico El Telégrafo, que se ocupa del tema, habría que señalar como culpable al propio Consistorio. La vehemente crítica hacia la actitud municipal así nos lo hace pensar:

No busquemos enemigos a Gran Canaria. Sus verdaderos enemigos, los que más dańo le hacen, son los que abandonan los derechos de esta población sin causa ni motivo que lo justifique. Para nosotros y con nosotros la ciudad de Las Palmas en masa, no ve más que una solución: destituirlos en las próximas elecciones de $\mathrm{Mayo}^{27}$.

Las cosas seguían como estaban y el mismo periódico, meses después, insta nuevamente para llevar a efecto la idea, sin que sus asertos lograsen eco alguno entre

25 Hernández Gutiérrez, Antonio Sebastián (1985): «Las Tipologías arquitectónicas», "Manuel de Oraá», en Basa, n. ${ }^{\circ}$ 3, nov. 1985, pp. 20-22. Una descripción del inmueble puede consultarse en Fraga González, Carmen (1999): El arquitecto Manuel de Oráa y Arcocha (1822-1889), Tenerife, Instituto de Estudios Canarios, p. 154. Valiéndose de unas fotografías, la doctora indica que consistía en un gran patio que recordaba la Recova vieja de la capital tinerfeńa, también de Oráa, puntualizando que «tres de los costados del patio tenían cinco -según parece-grandes arcos de medio punto sobre pilares, contraponiéndose la mampostería encalada de las paredes a los sillares de cantería en el contorno de los vanos; en el otro costado se incluía una escalera para salvar el desnivel del solar y permitir el acceso a las aulas que estaban detrás, lo que no sucedía con las dispuestas tras los otros lados». Una construcción, añade, que justifica que posteriormente se destinara a mercado de abastos.

${ }^{26}$ Galante Gómez, Francisco Javier: op. cit., p. 159.

27 «Pobre País». El Telégrafo, Las Palmas de Gran Canaria, 18-4-1887. 
los políticos ${ }^{28}$. Transcurridos tres años, siendo alcalde Fernando Delgado Morales, se da por fin el primer paso, ya que se aprueba solicitar al Gobierno una subvención del $75 \%$ sobre el importe global del futuro edificio, a ubicar preferentemente en el barrio de Los Arenales. Los delegados de la institución política, acompañados por el entonces arquitecto municipal, Laureano Arroyo, fueron los encargados de elegir el lugar escogido, decantándose por la explanada conocida popularmente como plaza de la Feria, de la cual, en opinión del facultativo, se podía tomar una parte sin perjuicio de la misma, habida cuenta de que resultaría «más regular sin reducción considerable en su perímetro» ${ }^{29}$.

Suponemos que en esta elección, en la que ahondaremos después, tuvo mucho que ver el hecho de que Triana y Vegueta ya estaban consolidados como distritos urbanos, contando, además, con distintas escuelas para ambos géneros, mientras que Los Arenales, conformado prácticamente a partir de la segunda mitad del Ochocientos, seguía creciendo, demandando más locales, así como hitos referenciales y de ordenación. De hecho, la plaza de la Feria, denominada popularmente de ese modo, al tratarse de una explanada en la que podían practicarse exhibiciones de ganado, productos, luchadas e incluso corridas de toros, llevaba ya algunos años preocupando a la municipalidad por carecer de un plan de urbanización adecuado y, sin duda, la ubicación de la escuela facilitaría la correcta reordenación del abandonado solar.

\subsection{EL PROYECTO}

En 26 de junio de 1891 Arroyo presenta al Consistorio los planos, el presupuesto y la memoria facultativa del edificio, cuya construcción valoró en 38 688,58 pesetas. En palabras del arquitecto, su configuración se ajustaba a los requisitos exigidos por el Real Decreto de 5 de octubre de 1883, que entonces regulaba la subvención gubernamental. El proyecto es aprobado aquel día y, en consecuencia, se determina la correspondiente tramitación ${ }^{30}$.

El sitio exacto elegido para su emplazamiento, el extremo oeste de la plaza, estaba situado justo en el centro del barrio de Los Arenales, un solar con una extensión de 60 metros de frente por 20 de costado, o sea, $1200 \mathrm{~m}^{2}$ en total. Sus laterales colindaban con calles de diez metros de amplitud, lo que facilitaría la libre circulación del aire y la incidencia de los rayos solares y que, a decir del arquitecto ofrecía, además de excelentes condiciones de ventilación, seguridad y desahogo para los niños, dado que el inmueble quedaría totalmente aislado y su frontis principal orientado hacia la extensa explanada ${ }^{31}$.

28 El Telégrafo, Las Palmas de Gran Canaria, 22-9-1887.

29 AMPLPGC. Libro de Actas del ańo 1890, sesión del 26 de septiembre, s. f.

30 AMPLPGC. Libro de Actas del año 1891, sesión del 26 de junio, s. f.

31 Archivo Histórico Provincial de Las Palmas (en adelante AHPLP). Sección Ayuntamiento. Serie Obras Públicas, leg. 11, exp. 202, año 1891. Documento n. ${ }^{\circ} 1$, memoria explicativa del proyecto para escuela de niños y niñas en el barrio de Los Arenales, s. f. 
El establecimiento, dividido interiormente en un par de escuelas, una para cada sexo, dispone también de dos patios anexos a ellas, ambos de 19 metros de largo por 10 de ancho, espacio estimado suficiente por la legislación entonces vigente para que los alumnos pudiesen ejercitar «las fuerzas corporales dando tregua a los trabajos de la imaginación y restableciendo así el equilibrio entre ambas partes». Estos espacios destinados al recreo se conciben de forma regular, con el fin de favorecer la vigilancia de los escolares. Pensando en su seguridad, se propone un suelo arenoso, más adecuado para los juegos infantiles que el duro pavimento, ya que amortiguaría los golpes de las caídas. Con la finalidad de que el ambiente resultase, climatológicamente, siempre agradable, fresco y protegido de la fuerza directa del sol, «que es de mucha intensidad en todas las estaciones del año», sugiere plantar distintas especies arbóreas y colocar en cada recinto una fuente, con grifo al alcance de los menores. Dos huertas dotadas con un par de cobertizos, destinados a gallinero uno, y otro a leñera, completan los espacios abiertos, disponiéndose ambas próximas a las dependencias de los maestros. En la galería lateral, que traza junto a los patios, ubica los urinarios, en franca comunicación con las aulas y dispuestos de modo que el profesor, desde su tarima, pudiese vigilar el acceso a los mismos de los escolares ${ }^{32}$.

Las viviendas de los maestros se diseñan separadas de las escuelas propiamente dichas mediante patios vallados, con la finalidad de que resultasen independientes tanto entre sí como respecto al cuerpo principal. No obstante, tal autonomía no debía obstaculizar la comunicación directa con las zonas dedicadas a la docencia, de manera que el arreglo y limpieza de las mismas no ocasionase grandes molestias durante los días de actividad escolar. En cuanto a su estructura y dimensiones nada se especifica en la memoria, si bien el arquitecto puntualiza que tan sólo dispondría de un número de estancias indispensables para satisfacer las necesidades domésticas, de forma muy modesta ${ }^{33}$.

En un lugar preferente del cuerpo central sobresale un salón, destinado a biblioteca, donde los niños podían acudir «luego que sepan leer libros de sanas doctrinas que despejen su inteligencia y fortalezcan su espíritu». Presenta un acceso independiente, de 6 por $4,10 \mathrm{~m}^{2}$, localizado en el vestíbulo de la zona destinada a las nińas. Uno de sus testeros quedaría ocupado por un armario a modo de estantería para los libros, y en el centro de la sala se deja espacio suficiente para ubicar una mesa con bancos para los lectores.

Las aulas tienen capacidad para cincuenta alumnos, siendo su superficie de $63 \mathrm{~m}^{2}$. La correspondiente a cada escuela se concibe precedida por un vestíbulo cuyo fondo tiene de ancho el mismo que aquéllas. Serviría de guardarropa, al tiempo que de espacio donde los estudiantes pudieran ordenarse antes de entrar, ya que tan sólo una cancela de hierro lo aislaría de la calle. Frente a dicho vestíbulo y, por tanto,

32 Ibidem. Estas dependencias, también garantizadas con adecuada ventilación, tendrían el piso elaborado en cemento Portland, material que, asimismo, revestiría las paredes hasta una altura de metro y medio.

\footnotetext{
33 Ibidem.
} 
también fronteriza a la puerta de acceso a cada clase, sitúa la mesa del maestro con el fin de que pudiese vigilar, a través de las cristaleras, lo que ocurría fuera.

También en su memoria, Arroyo describe detenidamente las ventanas del establecimiento, comentando razonadamente la ubicación de las mismas. Así, partiendo de la base de que éstas constituían el medio más importante de ventilación, siempre necesario en un edificio de esta tipología, y más aún en esa localidad, donde su acción se hacía notar a lo largo de todo el año, dado que la temperatura mínima no solía bajar en invierno de $18^{\circ} \mathrm{C}$, distribuye en cada sala diez ventanales, cuatro en cada uno de los muros laterales y dos en el testero principal, a ambos lados del estrado del profesor.

Pero no fue sólo el factor ventilación el que tuvo en cuenta el arquitecto a la hora de disponer la colocación de las ventanas, pues a éste suma el de una correcta iluminación, favoreciendo el hecho de que los alumnos no se vieran obligados a forzar la vista. En tal sentido, señala que tuvo presentes las alteraciones del órgano visual desarrolladas bajo la influencia de la vida escolar, las cuales podían resumirse en tres, que pasamos a transcribir para mostrar hasta qué punto, como siempre, Laureano Arroyo analizaba en sus proyectos diferentes cuestiones, a efectos de cubrir todas las necesidades derivadas de su tipología: «1. ${ }^{a}$ Miopía o disminución del alcance de la vista; $2 .^{a}$ Ambliopía o disminución de la agudeza visual; $3 .{ }^{a}$ Asthenopía o disminución de la fuerza traducida por la imposibilidad de continuar un trabajo durante un tiempo suficiente» ${ }^{34}$.

Basándose en criterios médicos, añadió que el origen de tales defectos visuales radicaba en la insuficiencia de luz en las aulas o en una combinación defectuosa de la misma. La solución a estos inconvenientes estribaba en proporcionar bastante luz por uno de sus costados y lo más alto posible, «lo cual se obtiene más fácilmente si la clase como en el caso presente es de forma oblonga con ventanas abiertas en uno de sus lados mayores del rectángulo o en los dos a la vez». Advierte, no obstante, que tampoco el exceso de iluminación resultaría ventajoso, y en base a ello recomienda el uso de persianas o cortinas para utilizarlas sólo en aquellos momentos en que se hiciese necesario mitigarla.

Coloca las ventanas a 1,90 metros del suelo, no sólo para provocar la correcta iluminación alta, sino también para aprovechar el espacio que debajo de ellas quedaba, en el que se podían colocar pizarras o carteles. Con el objeto de que proporcionasen la ventilación adecuada, las divide en bastidores móviles que facilitarían su giro en torno a un «eje inferior horizontal, estando fijo por el centro del puente superior una varilla que los abre o los cierra, según que baje o suba guiando el movimiento, un arco de hierro dentado que impide traspasar el límite de la abertura». Con este sistema, el aire entraría en el local en dirección de abajo arriba y, al chocar con el techo, se mezclaría en el interior sin corrientes perjudiciales para los chicos. Por esta razón, diseña los ventanales de forma rectangular, divididos en dos

${ }^{34}$ Ibidem. 
partes, la inferior fija, mientras la superior movible, facilita el ya comentado «sistema de báscula»" ${ }^{35}$.

El pavimento y los techos del edificio son otros de los aspectos minuciosamente explicados por el arquitecto. El primero, trabajado con tablas de riga, lo sitúa elevado - un metro por encima de la rasante natural-, con el fin de evitar el contacto directo con la humedad del terreno. La cubierta, de idéntica madera, la concibe sencilla y totalmente plana. Hace especial hincapié en prescindir incluso de elementos decorativos, tales como molduras, cornisas y escocias, pues los consideraba inútiles y, en su opinión, sólo servían para acumular polvo y telarañas.

En cuanto a los muros del inmueble, al objeto de abaratar los costes, Laureano Arroyo elude el uso de ladrillos, optando por la mampostería, mezcla de arena y cal en la debida proporción. Así, las superficies libres de las paredes se decorarían con figuras geométricas, preceptos de moral, cartas geográficas, carteles de lectura, etc. Para todo ello propone el uso del temple, sugiriendo la pintura al óleo para el zócalo, con el objeto de favorecer la limpieza. Era éste un aspecto a tener muy en cuenta en la edificación, de ahí que dictamine que los ángulos de las esquinas y de los techos se redondearan a efectos también de facilitar su lavado ${ }^{36}$.

En lo que respecta a la ornamentación externa del inmueble, el artífice indica que había procurado adaptarla a un punto intermedio, de manera que no acusara una extremada regularidad ni una profusión de adornos que ocultara el carácter de su cometido. Por tal razón, indicaba que la decoración se fundara «en los mismos datos de la disposición y construcción del edificio, acusándolos al exterior y haciendo comprender la satisfacción de sus necesidades». En tal sentido, añade que era necesario rehuir toda ornamentación que no fuese estrictamente motivada, procurando combinar la disposición de las masas con armonía y unidad en sus líneas. Había que lograr proporciones agradables entre vanos y macizos, resaltando el oficio de cada parte de la construcción, al contrastar los diferentes elementos mediante sus colores naturales: el zócalo de cantería, los marcos de los vanos imitando la piedra arenisca blanca, al emplearse revoque y estuco, los entrepańos emulando al ladrillo, la cornisa a elaborar en piedra, al igual que el pretil. El cuerpo central del edificio, donde, recordemos, localiza la biblioteca, se nos muestra coronado por un frontón triangular que simboliza la importancia de esta zona del inmueble ${ }^{37}$.

También se ocupa Arroyo de diseñar parte del mobiliario: el estrado del maestro, las mesas de escritura y otros accesorios. El primero debía elevarse sobre una tarima de 40 centímetros de alto, precedida por dos peldaños. Ubicada ésta en el testero fronterizo a la puerta de entrada, contiene la mesa con su pupitre. Delante de estas piezas traza una barandilla para aislar ese espacio del resto del aula.

\footnotetext{
35 Ibidem.

36 Ibidem.

37 Ibidem.
} 

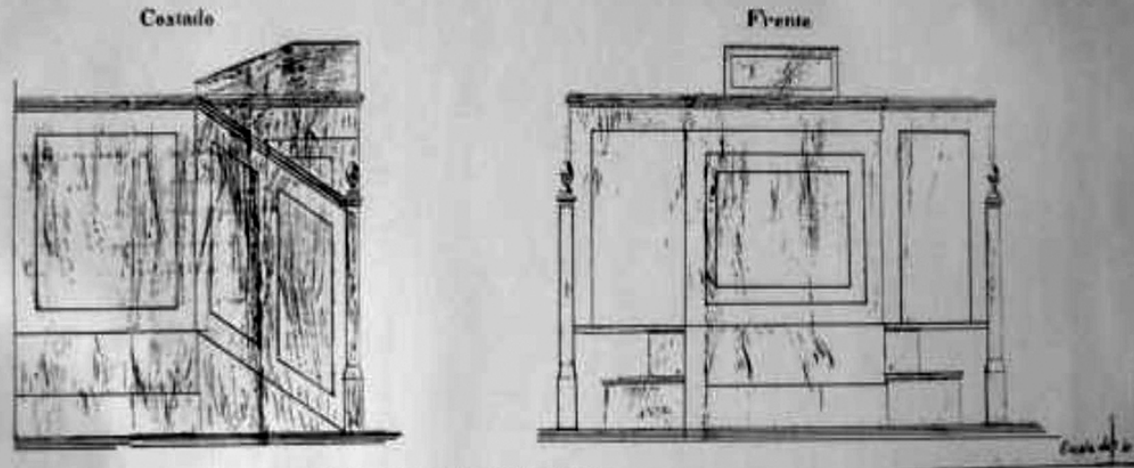

ISTAADO DEL MAESTAO.

Fig. 1. Estrado del maestro. Laureano Arroyo. Fuente AHPLP. Sección Ayuntamiento. Serie Obras Públicas, leg. 11, exp. 202, año 1891. Autora Ana M. ${ }^{a}$ Quesada.

Por su parte, los pupitres debían reunir las siguientes condiciones: $1 .^{\mathrm{a}}$, el borde exterior de las mesas y el interior del banco, estructurados en una sola línea vertical; 2. ${ }^{a}$, el asiento, integrado por banco y barra para apoyar los pies, con respaldo que se adaptase a la forma del cuerpo del alumno, rematando en línea recta el lado más próximo a la mesa; $3{ }^{a}$, dimensiones en perfecta proporción con la altura de los escolares; 4 . $^{a}$, los mismos, separados relativamente por el asiento que cada uno ocupara; $5 .^{\mathrm{a}}$, seis alumnos por cada mesa; $6{ }^{\mathrm{a}}$, inclinación variable, presentando la de $40^{\circ}$ para leer y la de $20^{\circ}$ para escribir, y $7 .^{a}$, cada niño ocuparía en las mesas un espacio de 50 centímetros lineales por 35 de ancho, y el de los bancos de 25 . Sobre éstos el arquitecto especifica que en la construcción se procuraría la mayor solidez y una disposición que permitiera fácilmente su reparación en caso de desperfectos, evitándose, por tanto, las disposiciones complicadas y los mecanismos de difícil uso o de costosa conservación.

Entre los accesorios destaca un armario con vidriera para custodiar libros, papeles, plumas y otros enseres. Lo dispone próximo al bufete del profesor, con dos metros de altura, uno de ancho y treinta centímetros de fondo. Las pizarras rodeadas de un marco, en cuyo lado inferior sobresale un cajón para el yeso, la esponja o cepillo, el compás, la regla y el puntero. En los vestíbulos distribuye perchas para los abrigos y gorras, además de aparatos especiales donde colocar los paraguas, trabajados éstos en madera o hierro, con un cajón en la parte inferior, forrado con plomo o zinc, para recoger el líquido que desprendiesen. No alude al diseño de otros aparatos destinados exclusivamente a la instrucción; caso de los instrumentos de física elemental, argumentando que se proyectarían, en su momento, en atención a las 


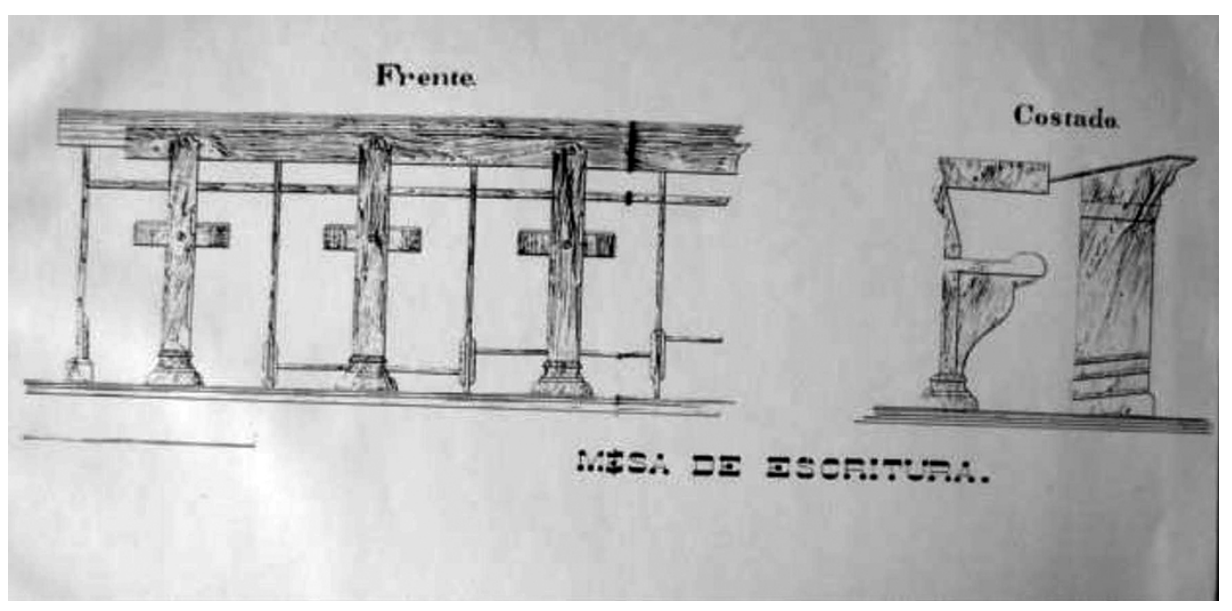

Fig. 2. Frente y lateral de los pupitres. Laureano Arroyo. Fuente AHPLP. Sección Ayuntamiento. Serie Obras Públicas, leg. 11, exp. 202, año 1891. Autora Ana Ma Quesada.

mejoras de que fuesen susceptibles los hasta entonces conocidos, «dados los adelantos modernos en pedagogía ${ }^{38}$.

Estas palabras aseveran hasta qué punto Laureano Arroyo quería siempre estar al corriente de las novedades que, de una forma u otra, pudieran estar vinculadas a la función de sus inmuebles, dejando hasta última hora aquellas cuestiones más sensibles a cambios, caso de los que frecuentemente se estaban sucediendo en el entorno docente. También en los siguientes párrafos vemos perfectamente cómo hace gala de ese carácter riguroso en relación con otros aspectos, sobre los que vierte decisiones meramente personales.

La descripción que hace sobre cada mueble y los comentarios acerca de sus caracteres no le impiden exponer otras observaciones más generales relacionadas con su elaboración. El primer requisito que había de satisfacer el mobiliario era la solidez, puntualizando al respecto que las maderas a emplear fuesen duras y resistentes. La seguridad constituye otra de las cuestiones resaltadas y para ello propone que las aristas y los ángulos se redondeasen, a efecto de que los golpes no resultaran peligrosos ni, a consecuencia de los mismos, se astillasen. También por motivos de seguridad, los bancos y las mesas debían estar sujetos al piso mediante unas bridas de hierro, mientras los cuadros y pizarras lo serían con escarpias.

Menos aún escapa a la atención del arquitecto el color de los pupitres. Exponiendo de nuevo una impresión que ratifica la minuciosidad que caracteriza a su 
personalidad, se opone a «la costumbre y al uso fundado sólo en la ley perniciosa de la rutina» de pintarlos de negro para que las manchas de tinta no se apreciasen. No le falta razón cuando argumenta que ello no contribuía a la limpieza; antes al contrario, la convertía tan sólo en apariencia, ya que la suciedad persistiría sin que se viera, al tiempo que los alumnos perdían interés en evitarla y los maestros no cuidaban de lavarlos. A ello se sumaba otro inconveniente, la mala impresión que ocasionaba a la vista, el duro contraste que provocaba tal color, en discusión con el blanco del papel. Expuestos los defectos de la tonalidad en cuestión, propone pátinas más claras que emulasen la madera, recomendando la utilización de la pintura al óleo para propiciar su frecuente aseo ${ }^{39}$.

Como es de rigor, las últimas páginas de la memoria recogen una sección dedicada al presupuesto global desglosado, coste de mampostería, albañilería, fabricación de ladrillos, pavimentos... ${ }^{40}$. Apartado significativo resulta, a continuación, el pliego de condiciones de las obras, que organiza en tres capítulos: el primero aludía a las que consideró como generales; el segundo, a las facultativas, y el tercero, a la parte económica. Las que afectaban al proyecto de forma general estaban enunciadas en quince cláusulas, en las que deja bien claro que como arquitecto y autor del proyecto, según estipulaba la ley, asumiría la dirección de los trabajos. Entre sus responsabilidades figuraban proporcionar las herramientas en buen estado, empezar las obras tan pronto como los responsables políticos las aprobasen y ejecutarlas durante un año, a contar de la fecha de admisión, siendo de su cuenta y riesgo las reparaciones por causa de la mala calidad de los materiales o deficiencias de la mano de obra. No podría traspasar el contrato y en caso de incumplimiento de sus obligaciones se interpretaría como una renuncia al mismo ${ }^{41}$.

Dentro del mismo capítulo, pero bajo el epígrafe «Ejecución de las fábricas», determina en qué parte del edificio se aplicaría cada material: sillería en molduras y mampostería en los muros de la fachada, en los de cerramiento de los patios, en algunos tabiques y, también, en la cubierta de la azotea, donde se alternaría con un

39 Ibidem.

40 Ibidem. Documento no 3, Presupuesto, s. f. Según apuntamos, el presupuesto global de las obras se estimó en 38 688,58 pesetas. Por el concepto de albañilería, englobaba movimiento de tierra, mampostería, fabricación de ladrillos, pavimentos, techos, cielos rasos, enlucidos, sillería y otros trabajos complementarios no especificados, se requerían 35 822,76 pesetas; las labores de carpintería - puertas, ventanas- ascendían a 2698,59; los costes de la pintura al óleo y al temple sumaban 1145,97 . Sobre la suma de las cantidades referidas $-35822,76$ pesetas- destinó un 3\% para gastos imprevistos y un 5\% para la dirección y administración de las obras, lo cual suponía 1074,68 y 1791,14 pesetas, respectivamente, para cada caso.

${ }^{41}$ Ibidem. Documento n. ${ }^{\circ} 4$. Pliego de condiciones, s. f. Asimismo, entre las condiciones que le afectaban indica que se haría cargo de la organización, valorizaciones y certificaciones. Se reservó el derecho al despido de los operarios que no cumpliesen y el de seleccionar los materiales, apartando los que no ofrecieran las condiciones idóneas. Emitiría las órdenes por escrito y podría exigir la demolición y reedificación de las partes que no se adaptasen al plano, siendo de cuenta del contratista la indemnización que correspondiese por la demora ocasionada. A su vez, el contratista debía reconocer su autoridad en todos los aspectos. 
entramado de madera, etc. Otra sección, denominada «Medios auxiliares», advierte sobre los útiles de trabajo ${ }^{42}$, mientras que las características de las piezas de carpintería configurarían el último grupo de observaciones aludidas en este segundo capítulo. Las clases de madera elegidas fueron tea, riga y pinsapo; la primera para los techos, la segunda para los entarimados, puertas principales y parte exterior de las ventanas, y la tercera para el resto de las piezas ${ }^{43}$.

De las condiciones económicas, desarrolladas en el último capítulo, entendemos que el contratista cobraría mensualmente, previa certificación de obras, aunque de las cantidades a librar se descontaría el 10\% como garantía. La medición lineal y la recepción de las obras se verificarían inmediatamente después de su conclusión, mientras que la liquidación final y la recepción definitiva se llevarían a cabo dos o tres meses después ${ }^{44}$.

\subsection{Rectificaciones al proyecto. Su Definitivo abandono}

El 24 de junio de 1891, Laureano Arroyo somete su proyecto a debate del Consistorio, que ese mismo día lo aprueba. El 8 de octubre, el consentimiento, adjunto al expediente incoado a efectos de solicitar la necesaria subvención estatal, se transmite al gobernador provincial, a fin de que lo gestionase ante el Ministerio de Fomento, lo que acontecería siete días más tarde, según consta en el oficio que con fecha de 23 del mismo mes remite al Ayuntamiento ${ }^{45}$.

Transcurridos tres meses, la Dirección General de Instrucción Pública devuelve los documentos con una serie de observaciones. En primer lugar advierte que si las habitaciones de los maestros iban a situarse, como se pretendía, en el mismo edificio, debían presentar accesos directos desde la calle, totalmente independientes a las entradas diseñadas para las dos escuelas. En segundo lugar, apreciaba defectos formales inherentes a los requisitos exigidos para la subvención. Al respecto, se denuncia la no remisión de un certificado en el que constase que el municipio se hallaba al corriente del pago de las atenciones de la enseñanza primaria. En tercer y último lugar, se requería que, una vez subsanados estos defectos, tanto la Junta de Instrucción Local como la Diputación Provincial emitiesen un informe a modo de aval ${ }^{46}$.

${ }^{42}$ Ibidem. En tal sentido, señala que eran necesarias cuerdas de cáńamo para elevar los materiales pesados y de esparto para atar los andamios; éstos se armarían bajo la vigilancia del contratista y debían contar «de pies derechos y tablones apoyados en los traveseros que unidos a dichos pies derechos por buenas lías de esparto vayan a descansar en la misma fábrica que se está levantando. Todos ellos contarían de tres tablones por lo menos, escogidos, sin nudos saltadizos ni otros defectos que acusen facilidad de romperse».

43 Ibidem.Al respecto, exigía un entablado perfecto y una especial atención en los empalmes y ensamblajes. Estas obras correrían por cuenta de un empresario especializado, quien debía proporcionar también las herramientas específicas y colocar todos los hierros que formaran parte de las piezas.

${ }^{4}$ Ibidem.

45 Ibidem. Oficio de la Delegación Especial del Gobierno en Gran Canaria (23-10-1891).

46 Ibidem. Oficio dirigido al Consistorio por el gobernador civil (4-2-1892). 


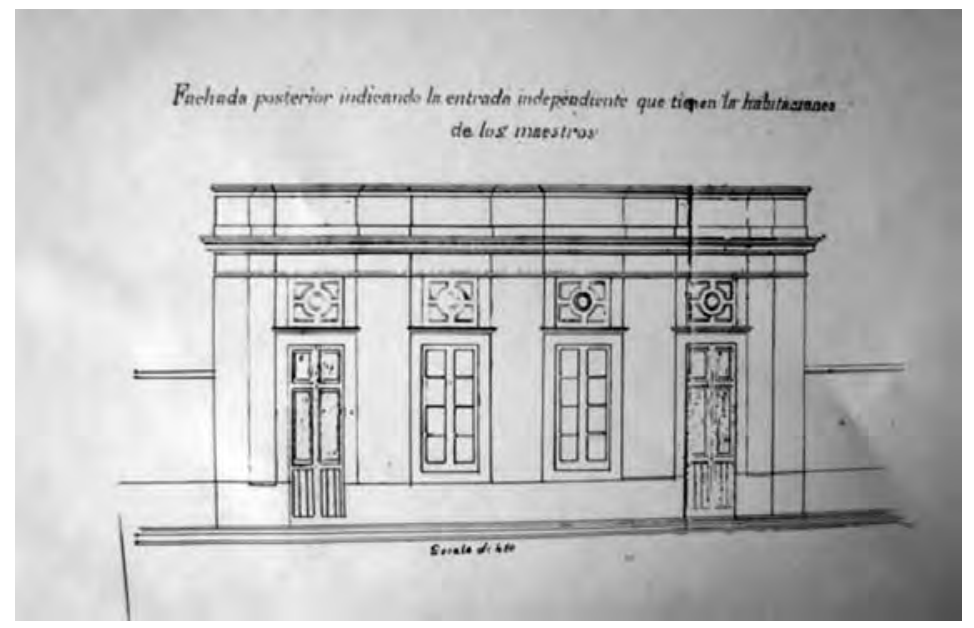

Fig. 3. Fachada posterior. Laureano Arroyo. Fuente AHPLP.

Sección Ayuntamiento. Serie Obras Públicas, leg. 11, exp. 202, año 1891. Autora Ana M. ${ }^{a}$ Quesada.

En sesión de 12 de febrero de 1892, el Ayuntamiento acuerda acatar las consideraciones ${ }^{47} \mathrm{y}$, en el mes de mayo, Arroyo presenta la remodelación del diseño, con entradas exclusivas para las dependencias de los docentes que, de ese modo, tendrían acceso directo, sin que fuera necesario recorrer el edificio ${ }^{48}$, modificación que no vendría a alterar en absoluto su fachada principal, ya que ahora las localiza en la parte posterior.

Para esas fechas, también Tomás Cardoso de los Ríos, a la sazón contador municipal, había redactado un escrito asegurando que la Administración local no tenía deudas en materia de enseñanza. Resueltas ambas cuestiones, ya sólo restaban los dictámenes de la Junta de Instrucción Local y de la Diputación Provincial. La primera se pronuncia favorablemente el 15 de mayo y, transcurridos tres días, lo hace la segunda ${ }^{49}$. A finales de este mes la documentación corregida es enviada a Madrid ${ }^{50}$.

En esta ocasión, el Ministerio de Fomento tardaría en atender la tentativa municipal, lo que da lugar a que en febrero de 1894, la Alcaldía se dirija al gobernador provincial pidiéndole que reclamase la devolución del proyecto para verificar

47 AMLPGC. Libro de Actas del año 1892, sesión del 12 de febrero, s.f.

48 AHPLP. Sección Ayuntamiento. Serie Obras Públicas, leg. 11, exp. 202, año 1891, Decreto municipal (13-5-1892).

49 Ibidem. Certificado rubricado por Tomás Cardoso (4-5-1892); dictamen de la Junta de Instrucción Pública local (15-5-1892), e informe de la Diputación Provincial (18-5-1892).

50 El Liberal, Las Palmas de Gran Canaria, 22-5-1892. 
una rectificación. Ésta, sugerida por la Real Sociedad Económica de Amigos del País, consistía en ampliar el edificio con el fin de que albergase la biblioteca popu$\operatorname{lar}^{51}$. Una decisión motivada, a nuestro juicio, por el creciente aumento de libros que albergaba la dispuesta en los salones bajos de las Casas Consistoriales, poco antes custodiada por dicha entidad y, en esos momentos, a cargo de la Comisión Municipal de Régimen Interior ${ }^{52}$.

Ignoramos si el político accedió a lo pretendido y si, de haberlo hecho, el Ministerio atendió la súplica, pero lo cierto es que éste no se dirigirá al Consistorio hasta un año después y nada consta en el oportuno oficio que nos induzca a pensar que ni tan siquiera tuviese conocimiento del último propósito comentado. Simplemente, se limitó a ordenar una modificación, haciendo referencia a la capacidad de las aulas, concebidas por Arroyo, como hemos dicho, para albergar a 50 alumnos. La Dirección General Pública trajo a colación la Real Orden de 5 de octubre de 1883 , entonces aún vigente, alusiva a las condiciones que habían de seguir los proyectos, y más concretamente su artículo 14, donde se especificaba que las clases debían estar preparadas para 60 escolares $^{53}$.

No deja de resultar sorprendente que el error ahora resaltado constase ya en la primera memoria, sin que entonces fuese recriminado. Esta indicación, de por sí manifestada con bastante demora, fue motivo de que la empresa se dilatase aún más. Los trámites burocráticos van a suponer un obstáculo, agravado por la distancia geográfica, tal como ocurrió en otras iniciativas municipales planificadas durante el último cuarto de siglo, entre ellas, la ampliación del cementerio y el ensanche de la ciudad hacia el puerto de La Luz, proyectos, por cierto, planificados también por Laureano Arroyo en calidad de arquitecto municipal.

51 AHPLP. Sección Ayuntamiento. Serie Obras Públicas, leg. 11, exp. 202, año 1891. Oficio municipal dirigido al gobernador provincial (27-2-1894).

52 Esta biblioteca pública tiene su origen, junto a un Gabinete de Historia Natural, en 1860, ubicándose en uno de los salones de las Casas Consistoriales. En 1868 los fondos de ambas dependencias fueron trasladados al Instituto de Enseñanza Media, pero, suspendido éste, regresan al inmueble municipal bajo la custodia de la Real Sociedad Económica de Amigos del País. Sin embargo, durante muchos años su acceso permaneció cerrado al público, hasta que en 1890 el Ayuntamiento encomienda la reapertura de aquellos bienes y su organización a la Comisión de Régimen Interior. La creación y desarrollo de la biblioteca ha sido investigado por los siguientes autores en diversas obras: Luxán Meléndez, Santiago de, y Hernández Socorro, M. ${ }^{a}$ Reyes (1988): «La creación de una biblioteca municipal en Las Palmas, 1860-1869: una página mal conocida de la vida cultural de la ciudad en el siglo XIX", en Anuario de Estudios Atlánticos, v. 34, Cabildo Insular de Gran Canaria, Madrid-Las Palmas, pp. 285-320; (1990): La difusión del libro en Las Palmas durante el reinado de Isabel II, Ediciones del Cabildo Insular de Gran Canaria, Colección Guagua, Las Palmas de Gran Canaria, pp. 28-31; (2005): El mundo del libro en Canarias, Ediciones del Cabildo Insular de Gran Canaria, Las Palmas de Gran Canaria, pp. 245-278. Al respecto, puede consultarse también AHPLP. Sección Ayuntamiento de Las Palmas de Gran Canaria. Serie Instrucción Pública, leg. 1, exp. 28, año 1860 , s.f.

${ }^{53}$ AHPLP. Sección Ayuntamiento. Serie Obras Públicas, leg. 11, exp. 202, año 1891. Informe evaluado por la Dirección General de Instrucción Pública, remitido por el gobernador civil (5-4-1895). 
En este caso, el órgano concejil no reparó en lo que consideramos una evidente irregularidad del Ministerio de Fomento y, servilmente, en sesión de 21 de junio resuelve cumplimentar lo ordenado y traspasar el expediente a la Real Sociedad Económica de Amigos del País, con la finalidad de que ésta aportara, una vez más, sugerencias respecto a la distribución del edificio, aprovechando la circunstancia de contar con el proyecto hasta que se procediera a su rectificación ${ }^{54}$.

La primera resolución no tuvo aplicación inmediata y de ello se culpa, precisamente, a la citada institución cultural, por sugerir una reforma radical en el inmueble, al pretender que no sólo albergase la referida biblioteca, sino también la sede de otra entidad instructiva para la urbe, El Museo Canario -entonces localizada también en distintas dependencias de las Casas Consistoriales ${ }^{55}$-, sin exponer concretamente las características de tal pretensión. Al menos, eso es lo que argumentó el arquitecto cuando el 7 de enero de 1897, transcurrido ańo y medio desde que el expediente fuera devuelto por segunda vez, y ampliada ya la capacidad de las aulas, responde al requerimiento municipal sobre el estado del expediente ${ }^{56}$. No hemos localizado el plano que supuestamente contenía tal variación, aunque sabemos que el proyecto reformado era aprobado en sesión plenaria del 22 del mismo mes y ańo, acordándose de nuevo someterlo a la anuencia superior ${ }^{57}$. Pero una vez más, la Dirección General de Instrucción Pública se demora en contactar con la Alcaldía y, cuando lo hace, en julio de 1898, es para requerir un nuevo documento, concretamente el duplicado de los croquis.

54 Ibidem. Extracto de sesión municipal (21-6-1895); AMLPGC. Libro de Actas del año 1895, sesión del 21 de junio, s. f.

55 La fundación de esta entidad hay que ponerla en estrecha relación con el interés que, desde mediados del siglo XIX, venía manifestando la comunidad científica de Las Palmas de Gran Canaria, por una serie de hallazgos de la cultura aborigen, fruto de diversas excursiones y excavaciones. El creciente desarrollo que experimenta la antropología en círculos europeos, el contacto que con ellos mantienen los investigadores locales y la necesidad de sistematizar los descubrimientos animan a su creación, contando ya desde sus orígenes con la colaboración de figuras tan destacadas en ese campo como lo eran los antropólogos René Vernau y Sabin Betherlot. El 2 de septiembre de 1879 , sus fundadores se reúnen con la clara intención de constituir un museo que, articulado en diversas secciones, expusiera al público las colecciones de ciencias naturales, arqueológicas y artísticas. Su intención contempla también la creación de una biblioteca que reuniera fondos modernos y antiguos, de temática preferentemente relacionada con las islas y, particularmente, con la de Gran Canaria. El Ayuntamiento era afín a los objetivos de la nueva sociedad, de modo que le cede para su ubicación los salones altos orientados al norte de las Casas Consistoriales, donde permaneció hasta 1923, ańo en el que se traslada al inmueble cedido por uno de sus fundadores, el Dr. Gregorio Chil y Naranjo, en la calle que lleva su nombre, en Vegueta, donde sigue desarrollando un papel fundamental para la cultura canaria. Sobre la historia de esta entidad, consultar preferentemente RodRíguez Doreste, J. (1967): El Museo Canario. Breve reseña histórica y descriptiva. Las Palmas de Gran Canaria, Ediciones El Museo Canario. Siemens Hernández, L. (1995): Libro azul de la Sociedad Científica. El Museo Canario, Las Palmas de Gran Canaria, El Museo Canario.

56 AHPLP. Sección Ayuntamiento. Serie Obras Públicas, leg. 11, exp. 202, año 1891, s. f. Oficio dirigido por Laureano Arroyo a la alcaldía (7-1-1897).

57 Ibidem. Extracto de sesión municipal (22-1-1897). AMLPGC. Libro de Actas del año 1897, sesión del 22 de enero. 
Ésta es la última referencia que sobre el asunto hemos encontrado; al respecto podemos barajar algunas hipótesis: $1 .^{a}$ finalmente, no se remitió la copia; $2{ }^{a}$ el Ministerio no llegó a aprobar la subvención, demorando el asunto, y $3{ }^{a}$ el Ayuntamiento, desmoralizado por las sucesivas dilaciones que sufría el proyecto, termina relegándolo al olvido. Lo cierto es que las escuelas diseñadas por el facultativo municipal no llegan a cristalizar.

Mejor suerte sonrió al municipio de La Orotava, Tenerife, a lo largo de estos últimos años, pues, valiéndose también de la citada Real Orden de 1883, el Ayuntamiento le encargaba a Manuel de Oráa la rectificación de los planos que Pedro Maffiote, años antes, había realizado para el edificio destinado a ser su sede y a otros usos, entre ellos al docente ${ }^{58}$. Los croquis y el presupuesto fueron desestimados en Madrid, de modo que se le solicita un nuevo alzado al arquitecto municipal de Santa Cruz, Manuel de Cámara, quien no presta atención al asunto. En 1890, su sucesor en el cargo, Antonio Pintor Ocete, interviene, procurando no alterar en demasía el planteamiento anterior, pero simplificando la fachada con el fin, en su opinión, de hacerla más sencilla. La ansiada ayuda económica quedaba resuelta a favor del Ayuntamiento orotavense el 15 de noviembre de $1892^{59}$.

\section{SIGNIFICADO Y CONTRIBUCIÓN DEL PROYECTO EN LA TRAYECTORIA DE LAUREANO ARROYO}

En diciembre 1877 la muerte sorprendía al entonces arquitecto municipal de Las Palmas de Gran Canaria, José Antonio López Echegarreta. El Ayuntamiento consideró entonces que la plaza vacante no tenía por qué ser ocupada por otro facultativo, ya que no existía intención alguna de proyectar edificios de carácter monumental, quedando una vez más la ciudad sin técnico de titulación superior ${ }^{60}$. Este argumento le valió para dejar en manos de Francisco de la Torre, maestro de obras, todo el ramo de Policía y Ornato ${ }^{61}$. La falta de arquitecto titulado persistirá hasta

58 El solar elegido fue el resultante del derribo, tras la Desamortización de Mendizábal, del convento de San José. Pedro Maffiote, ayudante del Cuerpo de Ingenieros, diseñó un edifico para Casas Consistoriales, juzgado de primera instancia, escuelas públicas, plaza de mercado y plaza de recreo. Galante Gómez, Francisco Javier: op. cit., pp. 151-152.

59 Ibidem. Sobre Manuel de Cámara y Antonio Pintor Ocete consultar Darias PrínCipe, Alberto (1985): Arquitectura en las Canarias Occidentales, 1874-1931, Santa Cruz de Tenerife, Servicio de Publicaciones de la Caja General de Ahorros de Canarias, pp. 131-163 y 175-278.

${ }^{60}$ Martín Galán, Francisco (1995): La formación de Las Palmas: Ciudad y Puerto. Cinco siglos de evolución. Las Palmas de Gran Canaria, Junta del Puerto de La Luz y de Las Palmas, p. 200.

${ }^{61}$ De ese modo, se le quiso premiar los buenos servicios que desde hacía años venía prestando al municipio. Del aprecio que los concejales sintieron por este profesional da buena cuenta el hecho de que se le asignaran 3000 pesetas en concepto de estipendios, idéntica suma que la que llegó a cobrar López Echegarreta en calidad de arquitecto municipal. AMLPGC. Libro de Actas del año 1879, sesión del 8 de enero, s.f. Sobre ambos profesionales consultar preferentemente Rodríguez DE Quintana, Miguel (1978): Los arquitectos del siglo XIX. Gran Canaria, Colegio Oficial de Arqui- 
julio de 1888, situación que entonces aprovecha Laureano Arroyo Velasco (18481910) para solicitar que se cubriera tal carencia a su favor. Adjuntó a la instancia su curriculum vitae, en el que expuso, entre otros, los siguientes méritos:

Haber desempeñado por espacio de varios años la plaza de arquitecto municipal en dos importantes poblaciones, el haber sido premiado en concurso público por el Excmo. Ayuntamiento de Barcelona; declarado apto para desempeńar la plaza de arquitecto de la Diputación de aquella Provincia y finalmente el estar desempeñando hoy el cargo de auxiliar primero de la Dirección General de las obras del importantísimo certamen Universal de Barcelona ${ }^{62}$.

El día 2 del indicado mes, incluso antes de que el órgano concejil diera lectura al contenido de la instancia, el noticiero local El Telégrafo publicaba la intención de Arroyo, acompañándola de otros datos positivos, como el hecho de haber obtenido un galardón por su proyecto en el concurso abierto para la reforma de la Gran Plaza de Cataluña en Barcelona, y haber sido encargado de las obras del Palacio de Bellas Artes en la Exposición Universal de dicha ciudad ${ }^{63}$.

No resulta desacertado pensar que la reseña fuese facilitada al periódico por Salvador Cuyás, en un afán de dar publicidad a quien era su amigo, pues se sabe que gracias a este personaje, oriundo de Cataluńa y residente entonces en Las Palmas, Arroyo tuvo noticias de la vacante que nos ocupa y decidió solicitar la plaza, con el ánimo de solventar una cuestión de índole personal, intentando que ésta, además, se aviniera de la mejor forma posible a su vida profesional. Su esposa padecía un mal que sólo se vería aliviado en climas cálidos, lo que justifica su deseo de trasladarse a vivir a la isla, de cuya bonanza climatológica le había informado el propio Cuyás ${ }^{64}$.

Los concejales debatieron en exceso la proposición de Arroyo y, conscientes de la conveniencia de crear una plaza de arquitecto municipal, se encomienda la elaboración de las bases que regirían la provisión del concurso ${ }^{65}$. Pero Laureano Arroyo no podía esperar y El Telégrafo anuncia su llegada a la ciudad para principios de agosto ${ }^{66}$. Y no se equivocó, ya que el acta de la sesión que celebró la Corporación el 17 del indicado mes registra una instancia del arquitecto, en la que solicitaba que se le permitiera desempeñar el cargo, al que aspiraba, con carácter interino,

tectos de Canarias, pp. 37-42 y 43-50. Sobre el citado maestro de obras debe consultarse Rosario LEÓN, M. ${ }^{a}$ Teresa (1994): «Tipologías en la construcción del maestro de obras Francisco de la Torre». Actas del X Coloquio de Historia Canario-Americana (1992), t. II, Las Palmas de Gran Canaria, Casa de Colón-Cabildo de Gran Canaria, pp. 995-1015.

${ }_{62}$ AMLPGC. Libro de Actas del año 1888, sesión del 6 de julio, s. f.

${ }^{63}$ El Telégrafo, Las Palmas de Gran Canaria, 2-7-1888.

${ }^{64}$ Tarquis Rodríguez, Pedro (1967): «Diccionario de arquitectos y canteros que han trabajado en las Islas Canarias (siglo xIx)», en Anuario de Estudios Atlánticos, n. ${ }^{\circ}$ 13, Cabildo Insular de Gran Canaria, p. 497.

${ }_{65}$ AMLPGC. Libro de Actas del ańo 1888, sesión del 6 de julio, s. f.

${ }^{66}$ El Telégrafo, Las Palmas de Gran Canaria, 7-7-1888 y 13-7-1888, s. f. 
hasta que tuviera lugar la elección definitiva del aspirante ${ }^{67}$. Aceptada esta solicitud, se determina que comenzara sus servicios el primer día de octubre ${ }^{68}$. Sin embargo, para esa fecha, Arroyo contaría ya en su haber con la plaza en propiedad, ya que el 14 de septiembre, una vez que el plazo del concurso quedó cerrado, el órgano concejil acuerda denominarlo arquitecto municipal, desestimando el currículum presentado por Antonio Pintor Ocete ${ }^{69}$.

Laureano Arroyo había nacido en Barcelona el 30 de agosto de 1847 y, estudiado en la Escuela de Arquitectura de Madrid, obteniendo el título en 1875. Pasados tres ańos trabaja de asesor para la Corporación de Gelida y poco después era arquitecto municipal de Caldas de Estrada. Por oposición pasa a desempeñar un puesto en la Diputación Provincial de Barcelona. En esta ciudad tuvo la oportunidad de trabajar en la Exposición Universal, tal como señalamos, y de colaborar activamente con Elías Rogent Amat en el ensanche ${ }^{70}$.

Por primera vez, la Corporación va a contar con un artífice que unía a su título superior el bagaje adquirido a lo largo de trece años de ejercicio laboral, en un entorno abierto a las influencias europeas. Era pues una persona madura, contaba ya con cuarenta y un años y un currículum nada despreciable. En él depositaron los munícipes las esperanzas y sobre su tablero un número de proyectos realmente apabullante. Nada más llegar se vio obligado a estudiar una serie de complicadas iniciativas municipales como la del ensanche de la ciudad, la urbanización de parte de las huertas de Triana, la alineación de la homónima calle mayor, la decoración de la Plazuela, etc. El mismo año de su arribada a la isla, se hizo con el cargo de arquitecto diocesano, siendo igualmente numerosa su producción de carácter religioso: la iglesia de Santa Lucía de Tirajana, el templo de Nuestra Señora de La Luz ${ }^{71}$, la iglesia y escuela de los padres claretianos ${ }^{72}$, la iglesia y casa franciscana del puerto de $\mathrm{La} \mathrm{Luz}^{73}$, por citar algunos ejemplos. Hasta su fallecimiento, acaecido el $20 \mathrm{de}$ febrero de 1910, realizó también trazas de múltiples viviendas y planificó la remodelación de antiguos inmuebles. En ambas actividades se trasluce una preocupa-

${ }^{67}$ AMLPGC. Libro de Actas del año 1888, sesión del 17 de agosto, s. f.

${ }^{68}$ AMLPGC. Libro de Actas del año 1888, sesión del 24 de agosto; El Telégrafo, Las Palmas de Gran Canaria18-8-1888, s. f.

${ }^{69}$ AMLPGC. Libro de Actas del año 1888, sesión del 14 de septiembre. Este último arquitecto, natural de Granada, ganó al año siguiente el certamen que, a fin de dotar una plaza análoga a la que nos ocupa, convocó el Ayuntamiento de Santa Cruz de Tenerife. Tomó posesión de su cargo el 20 de junio, permaneciendo al frente del mismo hasta 1932. Sobre el mismo véase Darias PrínCIPE, Alberto (1985): op. cit., pp. 175-314.

70 Tarquis Rodríguez, Pedro. (1967): op. cit., p. 497.

${ }^{71}$ Ibidem, pp. 500-501; Rodríguez Díaz de Quintana, M. (1978): op. cit., pp. 66-67.

72 Sobre esta edificación ver Rosario León, M. ${ }^{a}$ Teresa. del (1992): «La construcción de la iglesia y escuela de padres claretianos en Las Palmas», Rev. Vegueta, Las Palmas de Gran Canaria, 1992, n. ${ }^{\circ} 1$, pp. 285-292.

${ }^{73}$ Este proyecto ha sido estudiado por Hernández Socorro, M. ${ }^{a}$ Reyes (1994): «Arte y realidad. La frustración de un proyecto vanguardista en Las Palmas: la iglesia y casa franciscana del Puerto de La Luz». Actas del IX Congreso Nacional de Historia del arte (1992), León, Universidad de León, 1994, t. II, pp. 403-416. 
ción esencial: lograr la perfecta distribución del espacio interior acorde con las nuevas normas dictadas sobre higiene ${ }^{74}$.

El proyecto del edificio para escuelas le llega cuando llevaba ya tres años desempeńando el cargo de arquitecto municipal. En estas trazas inéditas, como vamos a ver, se perciben diversos aspectos que observamos en otras actuaciones suyas, lo que nos ha permitido corroborar algunos de sus rasgos, pero también nos deja al descubierto otros que favorecen una mejor interpretación de su obra y lenguaje.

Contribuir al planteamiento urbano de Las Palmas, referenciando su experiencia barcelonesa, fue una de sus principales intenciones. Cuando se hace cargo del proyecto, ya conocía perfectamente las necesidades de la ciudad, y por ello sospechamos que la ubicación designada para las escuelas no resultó nada aleatoria. Como ya avanzábamos, el inmueble iba destinado a Los Arenales, barrio que continuaba creciendo pero que aún carecía de un lugar de solaz adecuado para su vecindad, y qué mejor que destinar a ello la explanada de la Feria, donde desde hacía años los munícipes tenían puestos sus ojos, por constituir justamente el centro del caserío, al cual estructuraba en dos zonas, norte y sur.

En torno a 1867 se habían iniciado las edificaciones que configuraron su perímetro arquitectónico $^{75}$, tal como se deduce de la instancia presentada por un vecino que recaba la autorización municipal de una fábrica, aludiendo a los beneficios que con ella aportaba al aspecto público del lugar, "puesto que sin edificios aquella plaza es un desierto ${ }^{76}$. Pero la verdad es que pese a las viviendas que se fueron levantando en los sucesivos ańos, los distintos proyectos que se proponen para el uso de la plaza y su embellecimiento no se concretan, de modo que lo que encuentra Arroyo no es más que un amplio solar con escasa repercusión en la vida de la ciudad.

Por ello, creemos que vio en las escuelas el medio para estimular su implicación en el entorno, un hito arquitectónico que contribuiría a acotar el recinto por el este. Así, la relación entre urbanismo y arquitectura que siempre perseguía en sus proyectos se cumpliría, hasta el punto también de que la plaza, tal como sugiere en su memoria, se convertiría en un espacio de esparcimiento para la misma, un área que permitiría la comodidad de los niños tanto al entrar como al salir. Consideramos también que en esta simbiosis, la escuela aportaría un límite visual para el lugar, un telón de fondo para una escenografía urbana, en cuanto que orientaba su fachada principal hacia la misma, mientras que la parte posterior quedaba colindante a la carretera que unía Las Palmas con el puerto de La Luz, hoy calle de León y Casti-

74 Véase al respecto Hernández Lobo, Antonio (1993): «Primeras propuestas del arquitecto Laureano Arroyo: una nueva interpretación de la arquitectura de uso privado». Actas del IX Coloquio de Historia Canario-americana (1990), t. II, Las Palmas de Gran Canaria, Casa de ColónCabildo de Gran Canaria, pp. 1205-1223.

75 Ver algunos ejemplos de licencias para construir junto a la plaza en AHPLP. Sección Ayuntamiento. Serie Policía y Ornato, leg. 5, exp. 148-145, año 1867, s. f.; leg. 5, exp. 148.50, año 1867; leg. 6, exp. 172-173, ańo 1869. Al igual que otros inmuebles levantados en el barrio, éstos fueron delineados por Gregorio Guerra, miembro en esos ańos de la Comisión de Ornato del Ayuntamiento.

${ }^{76}$ AHPLP. Sección Ayuntamiento. Serie Policía y Ornato, leg. 5, exp. 148-34, año 1867. 


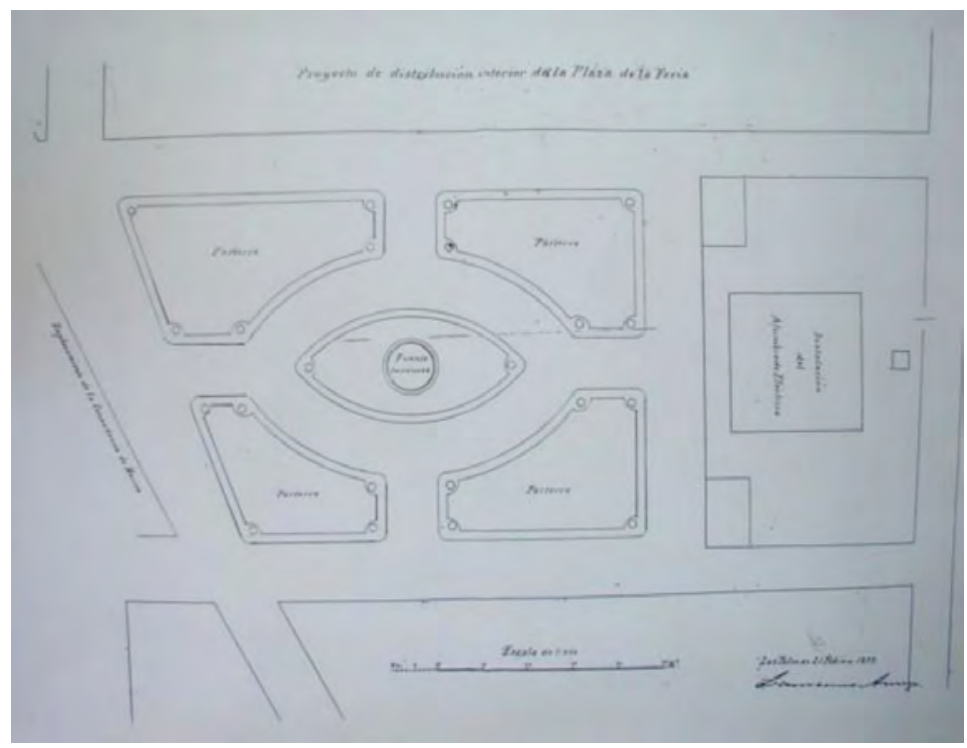

Fig. 4. Proyecto para ajardinamiento de la plaza de la Feria. Laureano Arroyo. Fuente AHPLP. Sección Ayuntamiento. Serie Obras Públicas, leg. 13, exp. 291, ańo 1899. Autora Ana M. Quesada.

$1 \mathrm{lo}^{77}$. Lógicamente, de abrir la fachada principal a dicha vía, el tráfico rodado haría peligroso el acceso de los grupos de escolares y, por otra parte, si le daba la espalda al recinto, su disposición le restaría importancia simbólicamente, eludiendo la posible prestancia del pretendido lugar para solaz urbano.

Es más, en 1896, cuando aún se estaba a la espera de la subvención económica del Ministerio, Laureano Arroyo, junto con Fernando Delgado, entonces arquitecto interino del municipio, elabora un plan de ornamentación floral. Acorde con los gustos de jardinería de la época, el centro de la plaza habría de ser ocupado por una monumental fuente, de la cual irradiarían seis grandes parterres, rodeados de caminos secundarios, con objeto de evitar un «jardín amanerado», geométrico, optando, por el contrario, por una interpretación más espontánea y de apariencia más cercana a la naturaleza ${ }^{78}$. Pero al igual que las escuelas, ni este planteamiento

77 Sin embargo, ese costado de la plaza ha quedado abierto hasta hoy en día, mientras que al este de la carretera mencionada, Laureano Arroyo proyectó la Comandancia de Marina. Sin embargo, el extremo oeste de la plaza se nos presenta acotado por el inmueble de la Delegación del Gobierno, al que la explanada sirve de antesala.

${ }^{78}$ AHPLP. Sección Ayuntamiento. Serie Arbolado y Jardines Públicos, leg. 1, exp. s.n., año 1914, s. f.; Quesada Acosta, Ana M. ${ }^{a}$ (1990): «La ornamentación arbórea en la planificación de Las 
ni la reforma ideada al año siguiente, a base de parterres, estatuas y fuentes luminosas $^{79}$, llegaron a buen término.

Precisamente la firme presencia de la vegetación en sus proyectos es otra de las cuestiones que debemos resaltar en este arquitecto. En ella valoró en exceso, independientemente del ornato, su capacidad de refrescar y sanear los ambientes, incidiendo en el arbolado como un medio para lograr espacios sombreados, máxime en un lugar en el que la incidencia solar es mayor que en otras provincias. Lo indicaba así en la memoria que nos ocupa, pero también lo propone, por ejemplo, cuando sugiere la conversión de las aceras de San Bernardo en un «boulevard parisien», sustituyendo unos arbustos raquíticos por plátanos de Líbano como los que tenía la Alameda ${ }^{80}$, o al ocuparse de redactar un proyecto de remodelación para la Plazuela, donde resuelve un paseo protegido por cuarenta y siete árboles de especies elegidas por el Ayuntamiento y que habrían de alternarse con palmeras ${ }^{81}$. Igual de significativa, en tal sentido, fue su pretendida ampliación del cementerio de Las Palmas, donde creía necesarias plantaciones en todas las calles de los distintos departamentos, hasta hacer un total de 112 árboles, equidistantes cinco metros entre sí; aunque deja elegir las especies a la Comisión de Cementerios, advierte de la inconveniencia del pino por ser un foco perenne de basura y no permitir vegetar a su sombra ninguna planta de adorno ${ }^{82}$.

Esta preocupación por el arbolado la entendemos vinculada a otra invariable suya, la higiene, que si bien era estimulada por la legislación de su época, él la quiso poner en práctica más allá de lo estipulado, tanto en las viviendas que proyectó, como ya apuntábamos más arriba, como en materia de urbanismo, disciplina en la que abogó por el trazado de vías amplias, en aras de conseguir fluidez para el tráfico y unas condiciones de habitabilidad dignas de su domiciliados, a los que no debía faltar ni la ventilación adecuada ni la incidencia solar ${ }^{83}$. Luz y aire fueron precisamente, como se recordará, los primeros elementos que justifican la ubicación de las escuelas en ese lugar, un punto óptimo, en su opinión, por estar contiguo a vías

Palmas de Gran Canaria durante el siglo XIX», Actas del IX Coloquio de Historia Canario-Americana, t. II, Las Palmas de Gran Canaria, Casa de Colón-Cabildo de Gran Canaria, 1993, pp. 1517-1518.

79 AMLPGC. Libro de Actas del año 1899, sesión del 1 de marzo; AHPLP. Sección Ayuntamiento. Serie Obras Públicas, leg. 13, exp. 291, año 1899.

${ }^{80}$ AHPLP. Sección Ayuntamiento. Serie Obras Públicas, leg. 11, exp. 245, año 1895, f.f. 1-2v.

${ }^{81}$ AHPLP. Sección Ayuntamiento. Serie Obras Públicas, leg. 10, exp. 151, f.f. $29-30$.

82 AHPLP. Sección Ayuntamiento. Serie Obras Públicas, leg. 7, exp. 133, año 1876, f. 95v. Quesada Acosta, Ana M. ${ }^{a}$ (2005): «Un espacio para la muerte: el cementerio de Las Palmas en el siglo XIX». En Sola Antequera, Domingo (coord.), Imágenes de la muerte. Estudios sobre arte, arqueología y religión. La Laguna, Servicio de Publicaciones Universidad de La Laguna, p. 314.

${ }_{83}$ Defender estas premisas le acarreó más de un disgusto y, sobre todo, la incomprensión de los vecinos, quienes no dudan en sostener polémicas posturas, cuando comprueban que el ensanche propuesto para las respectivas arterias en las que residían traía consigo la reducción considerable de sus propiedades. Un clima de insatisfacción vecinal respiró Arroyo, por aludir un ejemplo, al proyectar a fines de siglo la nueva demarcación de la calle Herrería, en Vegueta. Ver AHPLP. Sección Ayuntamiento. Serie Obras Públicas, leg. 13, exp. 195, año 1889, s.f. 
de diez metros de ancho, dimensiones que facilitaban la renovación del ambiente en el que transitaban los escolares. Pero no olvidemos que la necesidad de aseo en relación con la salubridad es contemplada también para el interior del inmueble, deteniéndose en explicar, por una parte, la distribución elegida para los ventanales $y$, por otra, la prohibición de elementos decorativos, tales como molduras, cornisas y escocias, por favorecer el depósito de polvo y telarañas.

Es más, sus declaraciones en contra de la rutina de pintar los pupitres de negro corrobora perfectamente la asociación que defiende entre salubridad e higiene. De un lado, lo oscuro niega aparentemente la suciedad y, de otro, dańa considerablemente a la vista, si lo oponemos bruscamente con el blanco del papel. Y en tal sentido, tampoco nos sorprende su estudio sobre las posibles deficiencias que pueden afectar a la vista en periodo escolar. Su alegato es ejemplo de cómo mantuvo siempre una estrecha relación entre los temas médicos y arquitectónicos.

Estilísticamente Laureano Arroyo se mueve entre el eclecticismo ${ }^{84}$, el historicismo y el modernismo; de este último se ha considerado uno de sus introductores en las islas. Aunque en su eclecticismo, tanto estructural como decorativo, las fórmulas medievalistas parecen predominar, lo cierto es que el edificio proyectado para escuelas está más próximo a un pequeño grupo de proyectos que concibió con preeminencia de signos clásicos, quizá por tratarse, en el fondo, de un edificio representativo de la municipalidad, una entidad dependiente del poder político, al que tradicionalmente se vienen asociando los signos lingüísticos de la arquitectura de la Antigüedad. Respondería por tanto a ese grupo de edificios de origen oficialista que, a decir del Dr. Galante Gómez, convive con otros lenguajes propios de la segunda mitad del siglo XIX, sosteniendo sus fórmulas clasicistas «cuyo lenguaje expresaba - no solo de manera formal, sino, además, por su contenido semánticouna evidente segregación arquitectónica en el tejido urbano» ${ }^{85}$.

La propuesta de Laureano Arroyo despliega una fachada estructurada en tres cuerpos, siendo el central más estrecho que los laterales. Cada uno de ellos presenta su propio acceso, el izquierdo para la escuela de niños, el del centro a la biblioteca y el de la derecha a la escuela de niñas, tal como se especifica en las respectivas placas de formato rectangular que coronan dichos accesos. Un frontón apoyado en pilastras delimita la parte central del inmueble, concediendo por tanto importancia a la biblioteca, que en este caso es la zona noble del inmueble, el símbolo del saber y el conocimiento. Todos los vanos del edificio, tres puertas y ocho ventanas, se encuentran simétricamente distribuidos, a modo de módulos separados por pilastras, una división que se proyecta en altura generando un antepecho decorado con círculos y rematado de trecho en trecho con un motivo ornamental que no podemos precisar y que se repite, con formato similar, pero inferior tamańo, sobre las pilastras que

${ }^{84}$ Sobre el eclecticismo de Laureano Arroyo consultar López García, Juan Sebastián (1985): «Notas para el eclecticismo en Canarias. Laureano Arroyo y la Candelaria de Ingenio», Boletín Millares Carló, n. ${ }^{\circ}$ 7-8, Las Palmas de Gran Canaria, Universidad Nacional de Educación a Distancia, pp. 243-248.

${ }^{85}$ Galante Gómez, Francisco J.: op. cit., p. 37. 


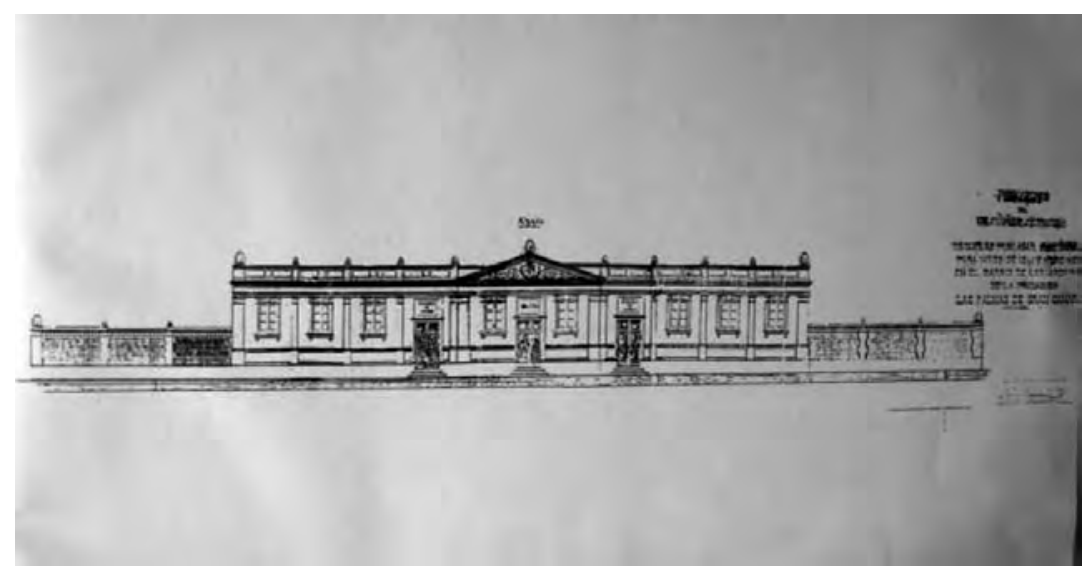

Fig. 5. Alzado del edificio para escuelas. Laureano Arroyo. Fuente AHPLP. Sección Ayuntamiento. Serie Obras Públicas, leg. 11, exp. 202, año 1891. Autora Ana M. ${ }^{a}$ Quesada.

también articulan los muros que prolongan la fachada por ambos extremos, cierre visual correspondiente a las huertas y zonas de ocio. La ornamentación que proporciona el armónico ritmo impuesto por los elementos arquitectónicos se acentúa por el enmarcado que lucen los vanos y por otros aditamentos singulares, como la vegetación que envuelve, en el tímpano del frontón, al escudo de la ciudad de Las Palmas de Gran Canaria, motivo inequívoco de la oficialidad del proyecto.

En definitiva, este diseño enriquece el catálogo arquitectónico de Laureano Arroyo, sumándose a la escasa producción de resabio clasicista que ofrece, aunque sin duda, por su función, resulta menos ambicioso que otros, caso de la Comandancia de Marina, que se concluye, ya fallecido, en la segunda década del pasado siglo $^{86}$, justo en línea paralela a la ubicación que debía tener la fachada del inmueble que nos ocupa. Quizá, la búsqueda de un mejor paisaje urbano para este segundo edificio justifique también la ornamentación de la plaza, su elección para ubicar en ella las escuelas y el estilo arquitectónico de las mismas. De estilo clásico renacentista, destaca el cuerpo central del frontispicio principal, trabajado en cantería azul de la isla. El frontón vuelve aquí a marcar la zona noble del edificio y, una vez más, es elemento parlante de la funcionalidad del edificio, ya que alberga en su interior varios motivos alusivos a la náutica, junto a las armas nacionales. Una balconada abierta en el segundo piso, apoyada en columnas exentas de orden dórico, le da prestancia al distinguido inmueble.

RECIBIDO: 20-5-2020; ACEPTADO: 11-6-2020

${ }^{86}$ Fraga González, Carmen (1976): Arquitectura Neoclásica en Canarias, Santa Cruz de Tenerife, Aula de Cultura de Tenerife, p. 45; Rodríguez de Quintana, Miguel: op. cit., p. 42. 